DOI: 10.17707/AgricultForest.61.3.17

\author{
Vesna DRAGIČEVIĆ, Branka KRESOVIĆ, \\ Živorad VIDENOVIĆ, Igor SPASOJEVIĆ, Milena SIMIĆ ${ }^{1}$
}

\title{
FITTING CROPPING TECHNOLOGY IN A CHANGING CLIMATE
}

\begin{abstract}
SUMMARY
Maize is one of the most important crops in the world. Its successful production depends mainly on meteorological factors. The aim of study was to define the most efficient tillage system (no-till, reduced or conventional tillage) and fertilizer amount (Ø, 330 or $660 \mathrm{~kg} \mathrm{ha}^{-1}$ of $\left.\mathrm{N}: \mathrm{P}: \mathrm{K}\right)$ for high maize yields (ZP 704) under rain-fed and irrigation conditions, according to the results of a longterm maize cropping experiment (1991-2010). The observed 20 year period was characterized by increasing trends of the average temperatures and sum of precipitation. A positive dependence between grain yield and precipitation was noticed only under rain-fed cropping. Weibull analysis emphasised that the highest yields were achieved with $330 \mathrm{~kg} \mathrm{ha}^{-1}$ of $\mathrm{N}: \mathrm{P}: \mathrm{K}$ fertilizer and conventional tillage under unfavourable conditions. Negative meteorological factors were diminished under irrigation, where high inputs resulted in increased yields. However, rain-fed cropping is still the most abundant cropping practice in the world, and moderate inputs (330 $\left.\mathrm{kg} \mathrm{ha}^{-1} \mathrm{~N}: \mathrm{P}: \mathrm{K}\right)$ resulted in stability of the maize yield, regardless of the lower yields achieved. On the other hand, the high yields attained with high fertilizer and tillage inputs under irrigation could be reasonable only in seasons with low precipitation (drought).
\end{abstract}

Keywords: maize cropping, fertilization, tillage, yield prediction

\section{INTRODUCTION}

Maize is one of the most important crops in the world. Successful production depends primarily on meteorological, but also on other environmental factors. It was found that climate change increase the disparities in cereal production between developed and developing countries (Rosenzweig and Parry, 1994), owing to the existence of vulnerability to the potential impact of global warming and extensive technologies (reduced fertilizer inputs and application of irrigation) in developing countries. Some of the effects of climate change which also affects the area of the Western Balkan include increased temperature, reduced total precipitation, increased number of summer days, extended period between the last spring and first autumn frost, increased sum of active air temperature above $10{ }^{\circ} \mathrm{C}$ (Čustović et al., 2012). According to Schlenker et al. (2002), the economic effect of climate change on agriculture requires different assessment for dryland

\footnotetext{
1 Vesna Dragičević, (corresponding author: vdragicevic@mrizp.rs), Branka Kresović, Živorad Videnović, Igor Spasojević, Milena Simić, Maize Research Institute "Zemun Polje", Slobodana Bajića 1, 11185 Zemun Polje, SERBIA.

Note: The authors declare that they have no conflicts of interest. Authorship Form signed online.
} 
(rain-fed) and for irrigated areas. In dryland areas, climate change is equivalent to an exogenous shift in the fixed input associated with new supplies. In irrigated areas, local climate is not directly connected to water supply. Risk reduction present in forecasting is a necessary part of any cropping practice (Igesias et al., 2011).

Variations in cropping practices, which include different measures, enable environmental factors to be overcome, especially during periods of extreme weather conditions for plant growth. Different studies concerning variations in cropping measures (tillage practices, fertilization amounts and rates) indicated that under rain-fed conditions on chernozem, conventional tillage is the best practice to lower energy inputs and increase maize yield (Videnović et al., 2011). Moreover, increased amounts of fertilizer could compensate yield deprivations arising from reducing some tillage operations (Tolimir et al., 2001). According to forecasting models, some inputs could be defined as necessary, while some others have no real effect on grain yield. Mechanistic models based on systems of nonlinear differential equations can help provide a quantitative understanding of complex physical or biological phenomena (Schlenker et al., 2002; Igesias et al., 2011). Forecasting in the variability present in a complex environment could be improved by non-linear models, such as the Weibull analysis (Kress et al., 1985a, 1985b).

The aim of this study was to define the most efficient tillage system (notill, reduced or conventional tillage) and amount of fertilizer (Ø, 330 or $660 \mathrm{~kg}$ $\mathrm{ha}^{-1}$ of N:P:K) for high maize yield (FAO 700 maturity group) under rain-fed and irrigation conditions, according to results of a long-term maize cropping experiment (1991-2010) under conditions of climate change.

\section{MATERIAL AND METHODS}

The research was conducted in Zemun Polje $\left(44^{\circ} 52^{\prime} \mathrm{N} 20^{\circ} 20^{\prime} \mathrm{E}\right)$, in the vicinity of Belgrade, on a slightly calcareous chernozem, within an ongoing longterm experiment, analyzing a 20-year period (1999-2010). The field experiment was arranged in a split-plot design with 4 replications. An elementary plot was $19.6 \mathrm{~m}^{2}(2.8 \times 7 \mathrm{~m})$ with a plant density of 64,935 plants/ha. Maize hybrid ZP SC 704 was sown with a four row planter for direct maize sowing (John Deere 7200 Max Emerge II), between the $20^{\text {th }}$ and $25^{\text {th }}$ of April every year, depending on the weather conditions.

The effects of three tillage systems were investigated: no-tillage (NT), reduced tillage (RT) and conventional tillage (CT). In the NT treatment, sowing was performed without preceding soil tillage. In the RT treatment, tillage was performed with a rotavator in the autumn (10-12 cm deep). The CT treatment consisted of shallow ploughing (15 cm deep) immediately after wheat harvesting, autumn ploughing (25 cm deep) and seedbed preparation with Rau-combi (composed of a harrow, cultivator and rollers). The fertilizer treatments included: control - without fertilization (Ø), incorporation of $330 \mathrm{~kg} \mathrm{ha}^{-1}$ of $\mathrm{N}: \mathrm{P}: \mathrm{K}(\mathrm{F} 1)$ and $660 \mathrm{~kg} \mathrm{ha}^{-1}$ of N:P:K (F2). The fertilizers were spread on the soil surface in the 
autumn. Both, tillage systems and fertilizer amounts were investigated in rain-fed and in irrigation cropping. Under irrigation, the soil moisture was maintained at $70-75 \%$ of the field water capacity content. The irrigation timing was estimated gravimetrically in 0-70 cm soil layer at 7-days intervals. The maize grain yield was measured from two inner rows and calculated to $14 \%$ of moisture.

Statistical analysis included regression analysis for the meteorological data, as well as for the dependence between the grain yield and meteorological condition (sum of precipitations and effective temperatures during vegetation GDD) in both rain-fed and cropping with irrigation.

The GDD value was calculated using the formula proposed by Cross and Zuber (1972):

$$
\mathrm{GDD}=\left(\mathrm{T}_{\max }+\mathrm{T}_{\min }\right) / 2-\mathrm{T}_{\text {base }}
$$

where $\mathrm{T}_{\max }$ is the maximum daily temperature (for $\mathrm{T}_{\max } \geq 30{ }^{\circ} \mathrm{C}$, it was considered as $30{ }^{\circ} \mathrm{C}$ ); $\mathrm{T}_{\min }$ is the minimum daily temperature (for $\mathrm{T}_{\min } \leq 10^{\circ} \mathrm{C}$, it was considered as $10{ }^{\circ} \mathrm{C}$ ); $\mathrm{T}_{\text {base }}$ was $10{ }^{\circ} \mathrm{C}$ for maize. The GDD values and the sums of the precipitation were calculated for vegetative period (AprilSeptember).

Differences between applied treatments in grain yield were presented with Weibull analysis (Dodson, 2006):

$$
F(x)=1-\mathrm{e}^{-\left[\frac{x}{\alpha}\right]^{\beta}}, \text { for } \mathrm{x}>0
$$

where $\beta$ is a shape parameter and $\alpha$ is a measure of the scale (characteristic life), which were used for the calculation of the survival probability, to predict a parameter reaching a reliability of $0.10,0.25,0.50,0.75$ and 0.99 .

\section{Meteorological conditions}

The observed 20 year period was characterized by increasing trends of both the sum of the precipitation and the average temperature (Figures 1 and 2), as well as by extreme meteorological conditions for maize growth, presented by a significant decrease in the difference between the maximal and minimal temperature.

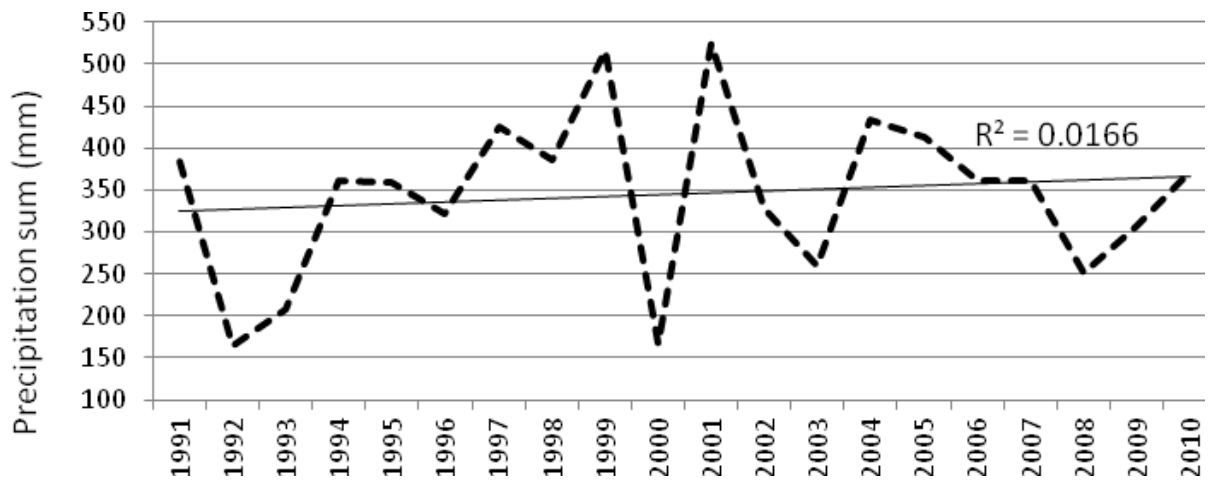

Figure 1. Precipitation sum during the examined period of 1991-2010 


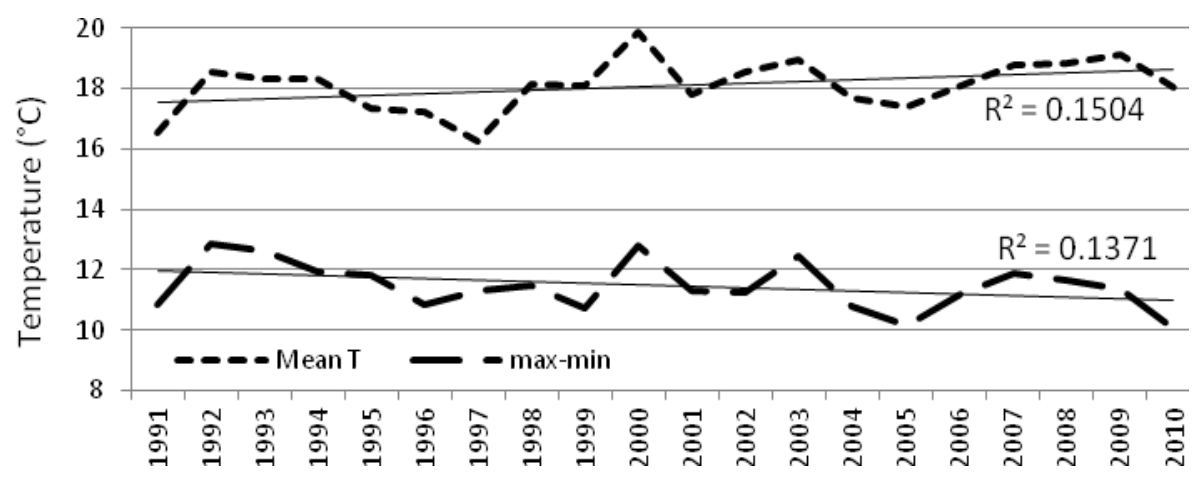

Figure 2. Mean temperature and difference between maximal and minimal temperature for vegetation period (from sowing to harvesting) during the period 1991-2010

Regarding the sum of the precipitation in the vegetative period, the years 1992, 2000, 2003 and 2008 were unfavourable with $\leq 250 \mathrm{~mm}$ (Figure 1). The same years were also characterised with high average temperatures (Figure 2), which was highlighted during 2000. Periods with lower temperature extremes were present during 1991, 1997-1999 and 2005.

\section{RESULTS AND DISCUSSION}

The present variations in the meteorological conditions induced variations in the achieved maize grain yield (Figure 3), which averaged 3.4-14.7 $\mathrm{t} \mathrm{ha}^{-1}$ in cropping with irrigation and 2.0-14.1 $\mathrm{t} \mathrm{ha}^{-1}$ in rain-fed cropping. The dependences between grain yield, amount of precipitation and GDD were insignificant under irrigation, which diminish the negative influences of environment. Schlenker et al. (2002) also emphasized that in irrigated areas, precipitation and temperature do not provide an accurate measure of the water supply available to farmers. On the other hand, rain-fed cropping was highly dependent on environmental factors, having a significant, positive correlation with the precipitation amount $\left(\mathrm{R}^{2}=0.117\right)$ and a negative correlation with GDD, which reveal the negative impact of high temperatures or prolonged vegetation on grain filling. From this point of view, precipitation was the dominant factor for the grain yield achieved in rain-fed cropping, while the temperature factor showed a smaller impact.

The application of different tillage practices in cropping with irrigation confirmed conventional tillage as the system which gave higher yield values at the same probability level (Figure 4). Thus, at probability level of $90 \%$ (unfavourable environmental conditions), a yield of about $9 \mathrm{t} \mathrm{ha}^{-1}$ could be realised in the control variant, whereas a yield of about $11 \mathrm{t} \mathrm{ha}^{-1}$ could be achieved in the F1 and F2 fertilization variants. The similar yield values at the F1 and F2 indicated that higher inputs of fertilizers did not realize the expected yield 
increase. Meanwhile, with reduced tillage, the yield was about $7 \mathrm{t} \mathrm{ha}^{-1}$ in the control and F1, and about $9 \mathrm{t} \mathrm{ha}^{-1}$ in the F2 variant, at the $90 \%$ probability level, meaning that increasing the fertilization rate induced a minor increase in grain yield. As opposed to conventional and reduced tillage, the no-till system showed the necessity for increased fertilization to increase yielding.
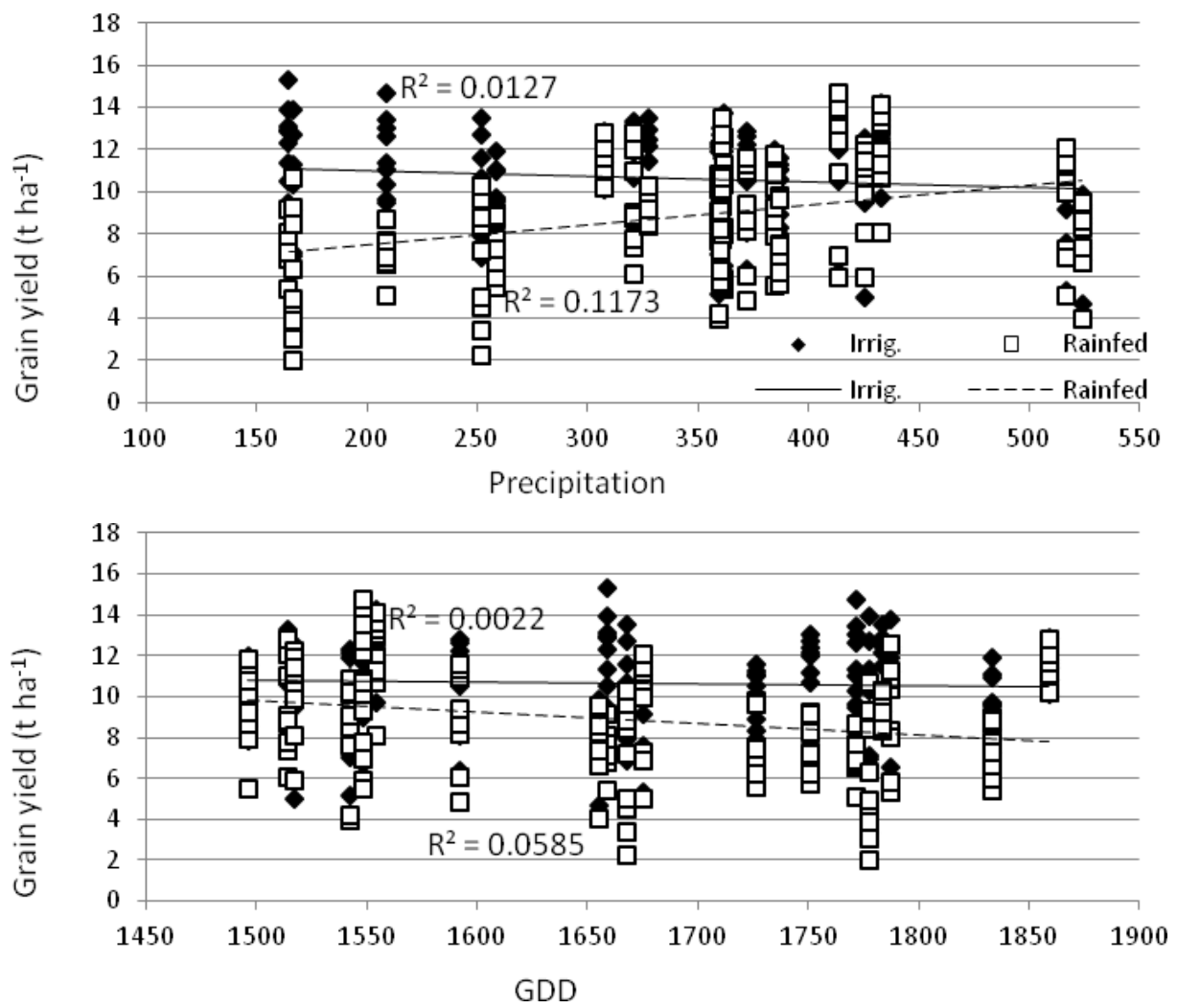

Figure 3. Dependence of maize grain yield on precipitation and GDD during vegetation in rain-fed cropping and cropping with irrigation

A grain yield of about $4.5 \mathrm{tha}^{-1}$ was achieved without fertilization, but 6.5 and $8.5 \mathrm{t} \mathrm{ha}^{-1}$ were realised in the F1 and F2 variants, respectively (probability level of $90 \%$ ). It is clear that the control variant emphasized the differences in the effect of the applied tillage systems, while the highest fertilization level - F2 reduced them. In conventional tillage as a system with highest realized yield, a smaller impact was obtained between the F1 and F2 variants. Tolimir et al. (2001) also found that increased fertilizer amounts could compensate the yield deprivations caused by reduction in the tillage intensity. 

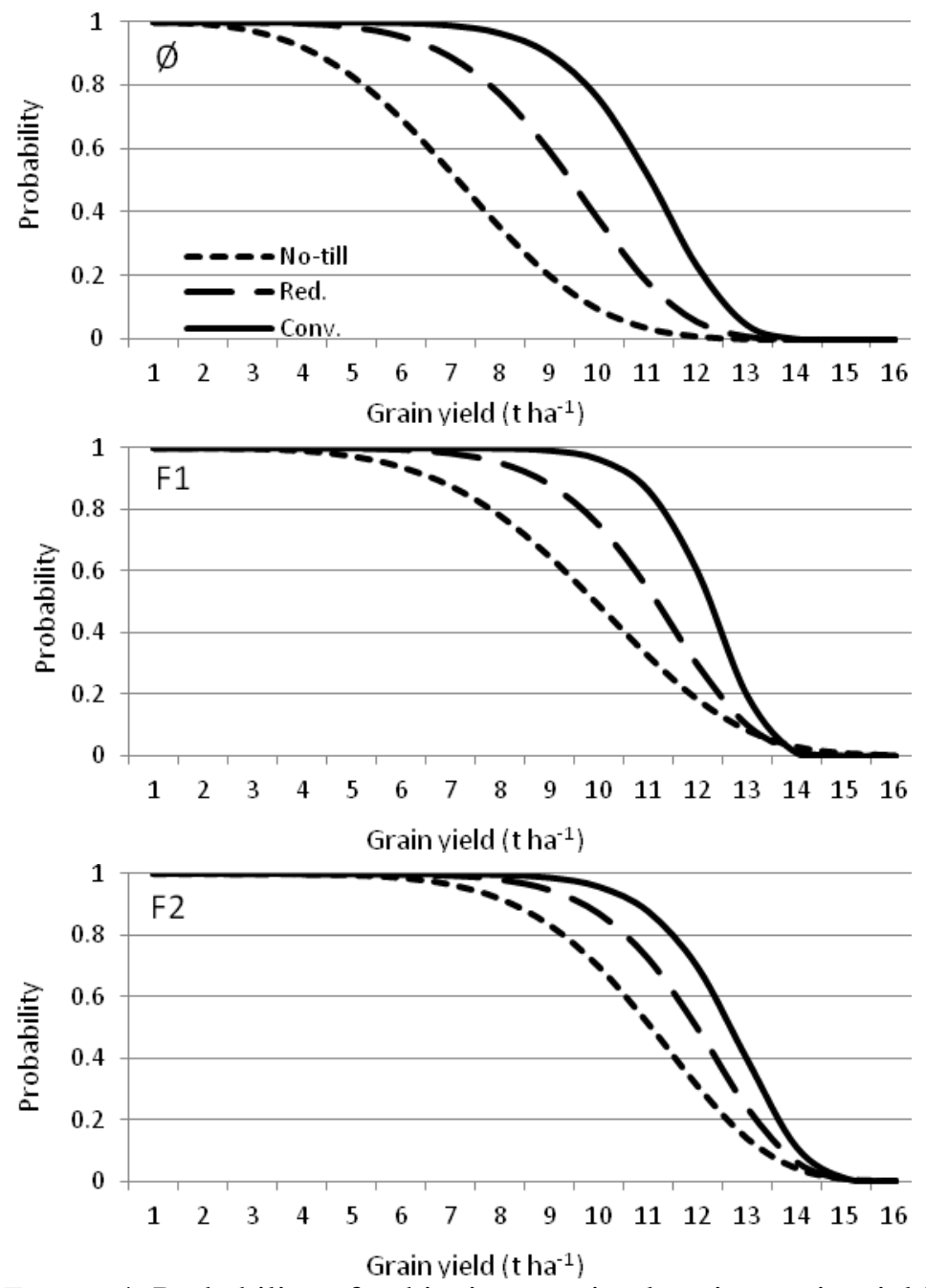

Figure 4. Probability of achieving maximal maize grain yield in cropping with irrigation at three levels of fertilization: $\varnothing$ - without fertilization, F1 - $330 \mathrm{~kg}$ $\mathrm{N}: \mathrm{P}: \mathrm{K} \mathrm{ha}{ }^{-1}$ and $\mathrm{F} 2-660 \mathrm{~kg} \mathrm{~N}: \mathrm{P}: \mathrm{K} \mathrm{ha}^{-1}$ and three tillage systems: no-tillage, reduced tillage and conventional tillage

At a probability level of $90 \%$, grain yields were lower in the rain-fed cropping than in cropping with irrigation (Figure 5). The highest yields were recorded in conventional tillage, in the range $7-8 \mathrm{t} \mathrm{ha}^{-1}$, in all three fertilization variants. In the other two tillage variants, the yields ranged from 6.5-7 $\mathrm{t} \mathrm{ha}^{-1}$ in reduced tillage, to about $5 \mathrm{t} \mathrm{ha}^{-1}$ in no-till practice. It is important to emphasise that differences between F1 and F2 were minor in rain-fed cropping, similarly to the results of Videnović et al. (1986) who ascertained that higher fertilizer amounts did not considerably affect yield in rain-fed cropping. 

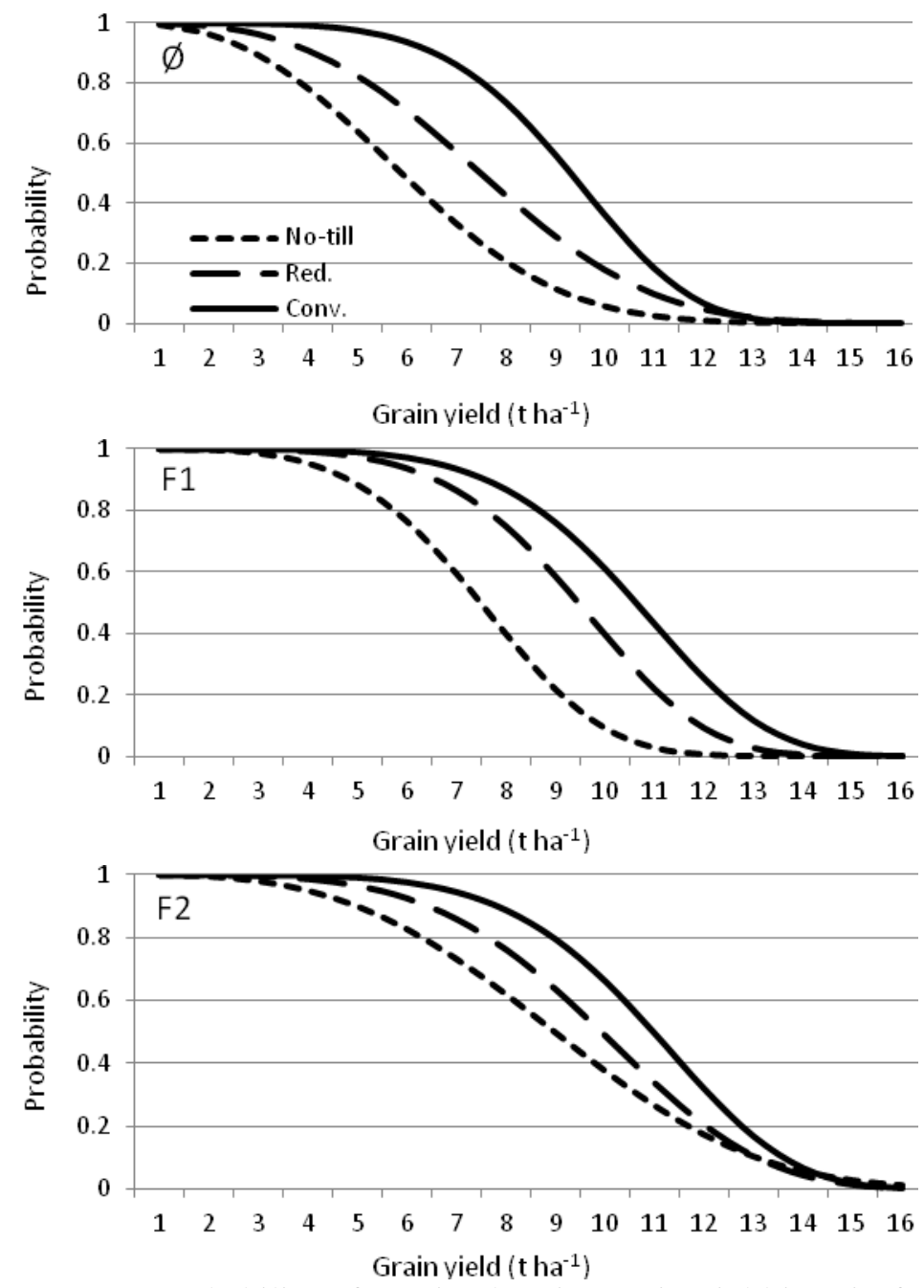

Figure 5. Probability of maximal maize grain yield in rain-fed cropping at three levels of fertilization: $\varnothing$ - without fertilization, F1 - $330 \mathrm{~kg} \mathrm{~N}: \mathrm{P}: \mathrm{K} \mathrm{ha}^{-1}$ and F2 $660 \mathrm{~kg} \mathrm{~N}: \mathrm{P}: \mathrm{K} \mathrm{ha}^{-1}$ and three tillage systems: no-tillage, reduced tillage and conventional tillage

Prediction of grain yield depends on the tolerance to many stress factors, including the amount of precipitation and temperature (GDD), which also reflects to plant development. In this 20 -year period, variations in meteorological factors induced variations in grain yield of examined maize hybrid. If a reliability of 0.10 is considered as the level with lowest environmental impact (sum of precipitation and temperature) and 0.99 as the reliability level with the highest environmental impact (Table 1), it could be assumed that higher variations were obtained in cropping with irrigation, irrespective of the highest values of achieved yield. Such a trend was mainly present for the control in no-till system 
(difference between yields at the 0.10 and 0.99 reliability level was $7.69 \mathrm{t} \mathrm{ha}^{-1}$ ), as well as cropping with conventional tillage in the F1 and F2 variants (difference between yields at the 0.10 and 0.99 reliability level was 5.39 and 4.25 $\mathrm{t} \mathrm{ha}^{-1}$, respectively). Other than irrigation, the variations in grain yield in rain-fed cropping did not exceed $2.46 \mathrm{tha}^{-1}$ (conventional tillage without fertilization).

At a reliability level of 0.10 , the potentially highest yield in the control could be achieved in no-till variant. On increasing the environment impact (reliability level over 0.50), the application of fertilizers induced yield increases more than irrigation did. The influence of fertilization to grain yield increase was emphasized in variant with reduced tillage, at all reliability levels. On the other hand, F2 was emphasized as the fertilization with the highest gain yield in variant with conventional tillage. An increase in reliability induced a decrease in differences between the fertilization levels.

Table 1. Prediction of maize grain yield $\left(\mathrm{t} \mathrm{ha}^{-1}\right)$ for different reliability levels (according to Weibull analysis), with three levels of fertilization and three tillage systems

\begin{tabular}{|c|c|c|c|c|c|c|c|c|c|}
\hline Tillage & \multicolumn{3}{|c|}{ No-till } & \multicolumn{3}{c|}{ Reduced } & \multicolumn{3}{c|}{ Conventional } \\
\hline Fertilization & $\varnothing$ & F1 & F2 & $\varnothing$ & F1 & F2 & $\varnothing$ & F1 & F2 \\
\hline Reliability & \multicolumn{9}{|c|}{ Cropping with irrigation } \\
\hline 0.10 & 9.95 & 5.14 & 6.98 & 6.51 & 8.50 & 9.54 & 9.89 & 15.35 & 12.51 \\
\hline 0.25 & 8.66 & 4.91 & 6.68 & 6.19 & 8.14 & 9.16 & 9.46 & 14.75 & 12.04 \\
\hline 0.50 & 7.17 & 4.60 & 6.30 & 5.78 & 7.67 & 8.67 & 8.91 & 13.95 & 11.42 \\
\hline 0.75 & 5.64 & 4.24 & 5.84 & 5.29 & 7.12 & 8.08 & 8.25 & 13.01 & 10.67 \\
\hline 0.99 & 2.26 & 3.10 & 4.39 & 3.79 & 5.34 & 6.18 & 6.17 & 9.96 & 8.26 \\
\hline \multicolumn{10}{|c|}{ Rain-fed cropping } \\
\hline 0.10 & 3.04 & 4.75 & 3.48 & 3.48 & 5.65 & 4.70 & 5.86 & 6.04 & 5.99 \\
\hline 0.25 & 2.82 & 4.46 & 3.31 & 3.28 & 5.38 & 4.49 & 5.57 & 5.77 & 5.74 \\
\hline 0.50 & 2.54 & 4.10 & 3.09 & 3.02 & 5.02 & 4.21 & 5.20 & 5.43 & 5.41 \\
\hline 0.75 & 2.23 & 3.68 & 2.83 & 2.72 & 4.61 & 3.88 & 4.76 & 5.02 & 5.02 \\
\hline 0.99 & 1.36 & 2.44 & 2.03 & 1.82 & 3.31 & 2.84 & 3.40 & 3.74 & 3.77 \\
\hline
\end{tabular}

In rain-fed cropping, the highest yields were recorded in the F2 variant for all three tillage practices and at all reliability levels. A greater environmental impact (increase in the reliability levels) decreased the differences between all three fertilization levels, indicating that increased inputs of fertilizers could be unfounded practice during unfavourable meteorological conditions. Only in conventional tillage the differences between the fertilization levels were evident with F1 and to some extent F2 fertilization levels, highlighting them as levels that could increase yields in the highest extent. In parallel, Videnović et al. (2011) also revealed the benefits of conventional tillage under rain-fed conditions, irrespective of the level of applied fertilizer. 


\section{CONCLUSIONS}

According to the obtained results, it could be concluded that irrigation diminished the negative influence of environmental factors on maize grain yield. The highest grain yields were recorded in conventional tillage and increased amounts of fertilizer. The increase of environmental impact induced a decrease in differences between fertilization levels, indicating that the best results in terms of grain yield could be achieved by conventional tillage and moderate amounts of fertilizers. Differences in the effect of the applied tillage systems were emphasized in the variant without applied fertilizers. The highest fertilizer level reduced the differences between the tillage systems, which could be used to compensate yield reductions, resulting from decreased tillage operations. In rainfed cropping, variations in obtained grain yield were several times lower than under irrigation. Higher fertilizer inputs in all three tillage systems could be unfounded practice during unfavourable meteorological conditions. The system with the highest yield under the unfavourable environmental impact is conventional tillage in combination with the fertilization level F1.

\section{ACKNOWLEDGEMENTS}

This study as part of the scientific project "Integrated Field Crop Production: Conservation of Biodiversity and Soil Fertility" (Reg. No. TR 31037) was supported by the Ministry of Education, Science and Technological Development of the Republic of Serbia.

\section{REFERENCES}

Cross, H. Z. \& Zuber, M. S. (1972): Prediction of flowering dates in maize based on different methods of estimating thermal units. Agronomy Journal., 64: 351-355.

Čustović H., Đikic, M., Ljuša, M. \& Žurovec O. (2012): Effect of climate changes on agriculture of the western Balkan countries and adaptation policies. Agriculture \& Forestry., 58: 127-14.

Dodson, B. (2006): The Weibull Analysis Handbook. 2nd Ed, Publ. W.A. Tony, American Society for Quality, Quality press, Milwaukee, USA

Iglesias, A., Schlickenrieder, J., Pereira, D. \& Diz, A. (2011): From the farmer to global food production: use of crop models for climate change, drought and agricultural production, In: Handbook on Climate Change and Agriculture, Robert Mendelsohn, Ariel Dinar, Edward Elgar Publishing Inc., Northampton, Massachusetts, USA, pp. 49-72

Kress, L. W. \& Miller, J. E. (1985a): Impact of ozone on field-corn yield. Canadian Journal of Botany., 63: 2408-2415.

Kress, L.W., Miller, J.E. (1985b): Impact of ozone on grain sorghum yield, Water, Air and Soil Pollution., 25: 377-390.

Rosenzweig, C. \& Parry, M. L. (1994): Potential impact of climate change on world food supply. Nature., 367: 133-138.

Schlenker, W., Hanemann, W. M. \& Fisher, A. C. (2002): The impact of global warming on U.S. agriculture: An econometric analysis, Department of Agricultural and Resources Economics and Policy Working Paper 936, University of California, Berkeley 
Tolimir, M., Kresović, B., Jovanović, Ž, Stefanović L. \& Videnović Ž. (2001): Tillage regimes and maize yield on chernozem. Zbornik naučnih radova Instituta PKB Agroekonomik., 7: 51 - 57

Videnović, Ž., Vasić, G. \& Kolčar, F. (1986): Effect of fertilizers and soil tillage on corn yield under dry farming and irrigated conditions. Soil and Tillage Research, 8: $113-118$.

Videnović, Ž., Simić, M., Srdić, J. \& Dumanović, Z. (2011): Long term effects of different soil tillage systems on maize (Zea mays L.) yields. Plant Soil and Environment., 57: 186-192. 